\title{
Keberhasilan Da'wah Nabi Muhammad: \\ Perspektif Stoddard
}

\author{
Isti'anah Abubakar \\ Dosen Fakultas Tarbiyah Universitas Islam Negeri (UIN) Malang
}

\begin{abstract}
The successful of missionary endeavor is very phenomenon thing. It is proven by many discussions about Islamic missionary endeavor, not only from Orientals but also our historian. Those discussions often emphasize in messenger's shape, so sanctify of messenger is imprinted to rise. This article tries to review the successful of Muhammad's missionary endeavor from sociology aspect, one of these in Stoddard perspective.
\end{abstract}

Keywords: missionary endeavor, messenger

\section{A. Pendahuluan}

Banyak pakar sejarah yang mengatakan bahwa Islam datang ke Jazirah Arab bukan pada masa vacuum cultural. Sebelumnya sudah ada agama peradaban atau agama seperti peradaban Greso-Romawi, peradaban Byzantium, peradaban Persia, peradaban Sino Confucianisme (Ruslan, 1983:20). Hal ini bisa dimaklumi karena Islam merupakan agama terakhir yang dipercayakan kepada Nabi terakhir Muhammad. Dikatakan juga bahwa Islam pada hakekatnya berfungsi untuk melengkapi dan meluruskan peradaban yang telah ada sebelumnya.

Dengan adanya peradaban-peradaban sebelumnya, maka secara otomatis terjadi apa yang namanya encounter of civilization yang berarti bertemunya dan bertatap mukanya peradaban yang sudah ada. Namun sekali lagi berlaku hukum alamiah yaitu siapa yang dapat membawa cita-cita yang lebih bernilai dan lebih progressif, siapa yang dapat mempraktekannya secara lebih unggul baik secara spiritual religius, scientific intelectual, kepemimpinan yang lebih bermoral, pengorganisasian yang lebih efektif dan efisien itulah yang akan unggul dalam encounter of civilization itu. 
Selama ini keberhasilan dakwah Islam selalu dikaitkan dengan sosok Nabi Muhammad sebagai pembawa agama Islam. Artinya, Islam tidak akan berhasil bila tidak dibawa Muhammad. Hal ini tercermin dari pendapat sejarawan Barat, semisal Edward Gibbon. Pendapat tersebut bisa jadi akan menjadikan seseorang mensakralkan Nabi Muhammad, padahal inti dari da'wah Nabi adalah ajaran Islam yang dikatakan sebagai pelurus dan pelengkap ajaran sebelumnya yang kesemuanya itu bertujuan untuk menyelamatkan hidup manusia.

Namun demikian, ada beberapa sejarawan Barat yang tidak berpatokan pada sosok Nabi Muhammad tapi lebih pada faktor sosiologisnya seperti yang diungkapkan oleh Stoddard dan Gustave E.von Grunebaum yang pendapat keduanya saling mendukung. Dikatakan Stoddard-bahwa keberhasilan Islam mencetak peradaban baru yang gemilang disebabkan 3 faktor yaitu, (1) the character of the Arab race (watak orang Arab), (2) the nature of Muhammad's teaching (hakekat ajaran Nabi), (3) the general state of the contemporary world-keadaan umum pada saat lahirnya Islam- (Stoddard, 1966:12). Ketiga faktor tersebutlah yang sangat mempengaruhi keberhasilan da'wah Islam dan hendak dikaji lebih mendalam tentang ketiganya, sehingga kita akan lebih obyektif menilai keberhasilan da'wah Nabi. Artinya bukan hanya dikarenakan Nabi sebagai seorang Nabi tapi ternyata terdapat faktor-faktor yang lebih rasional dalam keberhasilan da'wah Nabi.

\section{B. Pembahasan}

Da'wah Islam selama ini dipahami hanya sebatas pada kuatnya pengaruh wahyu. Artinya masyarakat mengiyakan atau mengamini saja bahwa keberhasilan dakwah Nabi pastilah terjadi karena ada campur tangan wahyu di dalamnya. Pembahasan keberhasilan da'wah yang dikupas Stoddard ini terasa lebih rasional dan obyektif dalam memahami Islam secara integral. Secara sadar kita -seorang muslim- pastilah mengakui bahwa perasaan subyektif dalam menganalisa Islam -dalam hal ini prespektif sejarah-masih sangat tinggi. Padahal dalam kajian studi Islam dikenal apa yang namanya Islam normatif dan realita (Muhaimin,2006) dan untuk mensikronkan keduanya diperlukan pandangan yang obyektif yang selanjutnya dapat menjadikan Islam bersifat dinamis. 


\section{Sekilas tentang Stoddard}

Lothrop Stoddard merupakan pengarang buku The New World of Islam (Dunia Baru Islam) dan The Rising Tide of Colour (Pasang Naik Kulit Berwarna) yang penerjemahannya diinstruksikan oleh Presiden Sukarno. Beliau adalah pengarang dari Amerika yang mempunyai ghirah yang tinggi dalam mendiskripsikan kemajuan Islam dari segi historisnya.

Penerjemahan yang merupakan intruksi Presiden Sukarno ini pada dasarnya dilandasai adanya keyakinan yang dapat mengggugah semangat masyarakat Indonesia-yang pada waktu dalam situasi penjajahan-untuk memahami apa yang ditulis oleh Stoddard yang selanjutnya dapat dijadikan penggugah semangat rakyat Indonesia.

Dari kedua buku tersebut dapatlah dipahami bahwa Stoddard merupakan seseorang yang mempunyai ghirah yang tinggi dalam menyingkap Islam dalam perspektif historisnya. Hal ini dikarenakan Islam oleh Stoddard dilihat sebagai kekuatan yang besar yang sanggup merubah segala sesuatu menjadi lebih baik.

\section{Keberhasilan Da'wah Islam Perspektif Stoddard}

Paparan berikut ini merupakan pembahasan mengenai keberhasilan da'wah Islam menurut Stoddard.

\section{The Character of Arab Race (Karakter Orang Arab)}

Sosok Nabi Muhammad-oleh banyak pihak (Mudjahid, 1994: 105)diyakini mempunyai peran strategis dalam keberhasilan da'wahnya di Timur tengah. Dengan kondisi yang sedemikian kompleks maka siapapun pastilah tidak mampu merubah dunia dalam waktu 23 tahun. Dalam catatan sejarah diketahui bagaimana kondisi Mekkah dan Madinah pada waktu itu. Sehingga siapapun yang mengetahui pastilah sepakat bagaimana sulitnya tantangan nabi dalam berdakwah.

Mekkah adalah kawasan padang pasir yang penuh konflik baik dikarenakan adanya fanatisme yang tinggi yang ini juga disebabkan adanya faktor geografis yang tandus dan gersang. Fanatisme dan keadaan geografis tanah Arab (Mekkah) secara gamblang dilukiskan oleh Ahmad Amin 
dalam bukunya "Fajr Islam". Secara geografis, Makkah dikatakan sebagai suatu lembah yang tiada mempunyai tumbuh-tumbuhan(Hitti, 1962:16), sedangkan Madinah yang sebelum Islam disebut Yatsrib lebat dengan pohon-pohon kurmanya (Amin:17). Sedangkan dari segi kemasyarakatan dilukiskan kalau keadaan Mekkah selalu dalam permusuhan dan peperangan. Ini bisa dilihat dari syair-syair, salah satunya dapat dijumpai di The Arabs A Short History, dikatakan: "Pekerjaan kami ialah untuk menyerang musuh, menyerang tetangga dan menyerang saudara kami sendiri, jika selain daripadanya tidak ada lagi orang yang akan diserang." (Amin:20)

Hal senada juga dijelaskan oleh Thomas Carley dalam bukunya on Heroes Hero Worship and The Heroic in History,:"....Itulah bangsa Arab (dikala itu) suatu bangsa petualang di gurun pasir, saling berhantam satu sama lain selama berabad-abad....".(Zuhri,1981:20)

Keadaan geografis yang sedemikian itu secara tidak langsung mempengaruhi karakter orang Arab di daerah tersebut. Maka sangatlah wajar bila kemudian, dituliskan bahwa orang Arab terkenal berwatak keras, fanatik atau ashabiyahnya kuat namun demikian terkenal juga kuat ingatannya. Hal semacam ini sampai sekarang dapat dibuktikan kebenarannya.

Kerasnya watak orang Arab terlihat jelas dari bagaimana alotnya mereka menerima suatu ajaran baru (dalam hal ini Islam) karena mereka tetap berpegang teguh terhadap ajaran nenek moyang, serta terlihat juga dari bagaimana cara mereka memblokir ajaran baru guna menyelamatkan ajaran lama mereka. Hal semacam ini kemudian ditunjang dengan adanya perasaan ashobiyah mereka antar satu dengan yang lain. Kerasnya bangsa Arab juga dilukiskan oleh Ibn Khaldun yang dikatakan sebagai bangsa yang kejam dan karakter ini terbentuk oleh penghidupan yang kasar yang harus mereka jalankan hingga kekasaran itu menjadi watak kedua bagi mereka selain suka mengembara (Khaldun, 1976).

Sedangkan faktor yang paling penting dalam karakter orang Arab ini adalah adanya ashabiyah yang kuat diantara mereka. Ashabiyah oleh Ibn Khaldun diartikan sebagai solidaritas sosial yang tidak saja didasarkan pada ikatan darah tapi lebih didasarkan pada kedekatan dan cara hidup 
yang sama dan bahwa hidup bersama itu bisa juga menimbulkan solidaritas yang sama kuatnya sebagaimana ikatan darah. Dan solidaritas semacam ini sangat kuat dalam masyarakat pengembara (masyarakat Arab terkenal sebagai kaum pengembara) karena corak cara hidup orangorangnya yang khas dan kebutuhan mereka akan saling bantu membantu yang sifatnya konstan.

\section{The Nature of Muhammad's Teaching (Hakekat Ajaran Nabi)}

Dakwah Nabi Muhammad yang mayoritas mendapat tantangan dari masyarakat sekitar pastilah mempunyai sebab. Demikian pula masyarakat yang menerima ajaran Nabi pastilah juga mempunyai sebab. Dalam Badri Yatim- yang dikutip dari Syalabi-dijelaskan ada 5 faktor yang menyebabkan masyarakat Mekkah menolak mentah-mentah ajaran Muhammad. (1) Mereka tidak dapat membedakan antara kenabian dan kekuasaan. Mereka mengira kalau tunduk kepada Muhammad berarti tunduk pada Bani Muthalib. (2) Menyerukan persamaan hak antara bangsawan dan hamba sahaya. (3) Tidak dapat menerima ajaran tentang kebangkitan kembali dan pembalasan di akherat. (4) Taklid pada nenek moyang adalah kebiasaan yang berurat akar pada bangsa Arab. (5) Pemahat dan penjual patung memandang Islam sebagai penghalang rezeki (Yatim, 1998:21).

Sedangkan menurut Lapidus, masyarakat Mekkah menolak ajaran Islam karena dianggap merusak tatanan masyarakat Mekkah. Bila ditelaah lebih lanjut, kedua faktor tersebut sama maksud namun beda redaksi. Lihat saja misalnya, perniagaan patung dan taklid terhadap nenek moyang. Sangat wajar bila kemudian dikatakan menggoncang tatanan masyarakat. Ajaran Islam melarang penyembahan patung disaat penjualan patung merupakan suatu profesi bagi beberapa masyarakat Mekkah. Seperti yang diungkapkan Lapidus, masyarakat Mekkah (saat itu) acuh akan sikap kedermawanan, acuh terhadap kesejahteraan kelompok masyarakat lemah, penuh dengan sikap kesombongan dan membanggakan kekuasaan manusia (Lapidus:33).

Selain relevansi kedua faktor tantangan Nabi di atas, dapat dipahami pula bahwa tantangan diatas juga disebabkan oleh karakteristik bangsa 
Arab. Lihat saja misalnya, mereka enggan untuk mengikuti ajaran Nabi Muhamamd karena akan dianggap tunduk terhadap Bani Muthalib (faktor 1), keengganan ini disebabkan masih adanya ashabiyah yang kuat, dan ashabiyah itu sendiri adalah karakteristik bangsa Arab sebagaimanan telah dijelaskan di atas

Sedangkan bagi yang pro atau welcome terhadap ajaran Nabi Muhamamd maka ada 2 faktor penting yang melatarbelakanginya yaitu,

(1) Ajaran Muhammad merupakan respon langsung terhadap lingkungan nyata atau setempat. Dalam Islam ditemukan kedamaian dan adanya kehidupan baru yang lebih baik melalui ibadah ritual, ketakwaan eskatologis. Realita sosial semacam itu yang menyebabkan beberapa orang tertarik mengikuti ajaran Muhammad, karena mereka kecewa terhadap pergeseran moral dan sosial yang terjadi pada saat itu. Dalam ajaran Muhammad itulah yang merupakan respon langsung terhadap lingkungan nyata ditemukan kedamaian dan kehidupan baru yang lebih baik melalui ibadah ritual, ketakwaan eskatologis, keagungan etik dan shalat.

(2) Adanya kesesuaian dengan agama sebelumnya serta nilai-nilai masyarakat yang terpendam.

Ajaran Nabi Muhammad juga, menurut Hitti serupa dengan ajaran Nabinabi Ibrani dari Injil Perjanjian Lama, yaitu hanya satu Tuhan, Ia Maha Kuasa Ia Pencipta seluruh alam, ada satu hari pengadilan di akherat, berbahagialah orang di dalam sorga jika tawakkal kepada perintah Allah dan beroleh siksaan berat di dalam neraka jika ia ingkar kepada perintahperintah itu. Zakat misalnya -serupa dengan persaudaraaan klan yang menyertai kehidupan mereka, Haji merupakan ritual yang berasal dari sebuah upacara masyarakat Arabia kuno. Hal ini juga dikuatkan oleh Ira Lapidus bahwa ajaran Nabi Muhammad sebagai respon langsung terhadap lingkungan setempat. Dan ajaran ini selaras dengan ajaran Kristen yaitu mengenai hari kiamat (Lapidus:33).

Selain itu pandangan yang lebih akan hal ini didapatkan dari pandangan orientalis dari Amerika bahwa Islam membawa 3 inti ajaran Islam yang sekaligus pembeda dengan ajaran sebelumnya yaitu: 


\begin{tabular}{|c|l|l|}
\hline No & \multicolumn{1}{|c|}{ Sebelum Islam } & \multicolumn{1}{c|}{ Islam } \\
\hline 1 & $\begin{array}{l}\text { Tidak memikirkan hari akhir } \\
\text { atau tidak ada } \\
\text { kesinambungan }\end{array}$ & $\begin{array}{l}\text { Antara di dunia dan diakherat } \\
\text { Kesinambungan antara }\end{array}$ \\
\hline 2 & Kehidupan akherat dan & Kehidupan dunia \\
\hline 3 & $\begin{array}{l}\text { Lebih terfokus pada } \\
\text { individual Selain kehidupan } \\
\text { pribadi, mengajarkan cara- } \\
\text { cara }\end{array}$ & $\begin{array}{l}\text { Kehidupan bermasyarakat dan } \\
\text { bernegara. Tidak menekankan } \\
\text { pada pengamalan norma hukum } \\
\text { dan moral. Lebih menekankan } \\
\text { pada pengamalan norma hukum } \\
\text { dan moral }\end{array}$ \\
\hline
\end{tabular}

Dari paparan diatas dapatlah dipahami selanjutnya bahwa hakekat ajaran nabi -terkandung dalam Islam itu-merupakan ajaran yang lengkap. Hal ini diperkuat dengan pendapatnya J. Harris Proctor yang mengatakan:

Islam is not only set of religious ideas and practioses but also a political community endowed with a system of law designed to protect the collective interest of believers and to regulate their relations with the outside world (Zuhri,1981:21). (Islam tidak hanya merupakan seperangkat yang lengkap dari cita-cita yang mulia dan praktekpraktek keagamaan, melainkan juga merupakan suatu tata kehidupan masyarakat berpolitik yang dilengkapi dengan sistem undang-undang yang tersusun guna melindungi kepentingan bersama para pemeluknya dan untuk mengatur mereka dalam hubungannya dengan dunia luar).

\section{The General State of the Contemporary World (keadaan umum dunia pada waktu lahirnya Islam).}

Berbicara mengenai keadaan umum di Timur pada saat lahimya Islam dapat dikatakan sedang dalam puncak-puncaknya kekacaubalauan, amat sengsara dan penuh derita. Di seluruh permukaannya tidak dijumpai wajah yang layak dibanggakan, segala-galanya mendendam risau gelisah dimanamana menjalar onar belaka. Dari deskripsi tersebut maka dapat dispesifikkan menjadi 3 aspek, yaitu, (1) Kepercayaan (baca: agama), (2) Moral, (3) dan Mu'amalahnya (sosial kemasyarakatan).

Dari aspek kepercayaan, dapat dikatakan bahwa kepercayaan yang beredar jauh dari logika atau rasionalitas. Penyembahan berhala, kayu-yang notabene lebih rendah derajatnya dari manusia-, cara mereka menganut 
agama adalah tiruan belaka. Di Parsi agama Zoroaster jatuh menjadi agama Majusi yang batil pusat penipuan pendeta yang berlagak gagah memperalat agama untuk bertindak kejam. Di Rumawi Timur, agama Nasrani diberi baju palsu dan dicampur adukkan dengan filsafat-filsafat Yunani yang dekaden sehingga dengan demikian mencerminkan suatu karikatur yang tidak baik dari ajaran Kristus. Kedua agama, Nasrani dan Majusi penuh dengan berbagai bid'ah dan kesesatan. Hal senada juga diungkapkan oleh Syed Ameer Ali dalam bukunya Api Islam, bahwa pada saat itu agama-agama saling bersaingan dan madzhab-madzhab yang saling menghancurkan, bertengkar dihadapan tubuh Tuhan yang katanya disembahnya (Ali, 1956:71).

Secara moral pun jauh dari yang diharapkan, banyak dijumpai orangorang yang hidupnya bergelimang dengan dosa serta laku durjana menikmati kesenangan hidup dari merebut milik orang lain yang diperkosa. Orang mabuk dimana-mana, mabuk karena kekayaan, melimpah ruah hasil perampokan dan perampasan, juga mabuk kekuasaan tanpa batas (Ali, 1956: 47). Keadaan moral saat itu juga dapat dipahami dari deskripsi Dja'far Ibnu Abi Thalib takkala ditanya Najasi (raja Habsyi), “.... Kami dahulu adalah bangsa Jahiliah, dizaman itu kami menyembah berhala, memakan bangkai, mengerjakan yang keji-keji, memutuskan tali kekeluargaan dan merusak tata tertib bertetangga yang kuat memakan yang lemah (Syalabi: 20).

Sedangkan dari aspek sosial kemasyarakatan dapat dipahami syair salah seorang penyair: Seharusnya sang penggembala melindungi dombanya dari ancaman serigala namun betapa pula jika sang penggembala sendiri adalah serigala-serigalanya?(Zuhri:6) Keadaan sosial kemasyarakatan ini dikatakan Hitti sebagai zaman jahiliah yang diartikan sebagai zaman kepicikan, kebiadaban (Hitti, 1962:22). Lebih jauh dapat dikatakan bahwa para penguasa berkomplot menindas rakyat, memenangkan kaum yang kuat dan orang-orang kaya.

Kekacaubalauan diatas secara tidak langsung telah menimbulkan rasa kecemasan, kehinaan, ketakutan dan penderitaan. Hal inilah yang menyebab-kan beberapa orang tertarik pada ajaran Muhammad dikarenakan mereka merindukan suasana damai. Mereka juga dikatakan sebagai kaum yang haus kesopanan dan peradaban. Bukti kongkrit terjadi pada Zaid yang 
kemudian dijadikan anak angkat oleh Muhammad, dimana ia tidak mau kembali kepada ayah dan kaumnya dikarenakan tertarik oleh perlakukan Muhammad yang sangat baik yang secara tidak langsung telah menimbulkan perasaan berbakti yang mutlak.(Ali,1956:70)

Ke-3 faktor keberhasilan da'wah Nabi oleh Stoddard diatas dapat dikatakan bahwa menyebarnya Islam sebagai agama yang rahmatan li al 'alamin bukanlah sesederhana membalikkan telapak tangan, selain itu juga semakin meneguhkan kita bahwa tersebarnya Islam bukan dikarenakan sosok pribadi Muhammad an sich, tapi lebih dikarenakan ajaran Islam yang merupakan kebutuhan bagi masyarakat tersebut. Ini semakin dibuktikan dengan adanya perubahan-perubahan yang dilakukan Islambagi masyarakat Arab pada waktu itu. Perubahan-perubahan itu, adalah(Syalabi:21-36)

(1) dari sering berperang ke jalan damai,

(2) dari kekuatan ke undang-undang,

(3) dari balas dendam ke Qisas,

(4) dari serba halal ke Kesucian,

(5) dari suka merampas ke kepercayaan,

(6) dari sifat suka mengasingkan diri sampai dapat menguasai negeri Persia dan rumawi,

(7) dari kehidupan kesukuan berganti dengan sifat rasa tanggung jawab pribadi,

(8) dari penyembah berhala ke Aqidah tauhid,

(9) dari memandang rendah wanita menjadi memuliakannya,

(10) dari sistem kasta ke persamaan.

Perubahan-perubahan di atas secara tidak langsung menunjukkan adanya situasi yang tercipta dengan datangnya Islam, situasi yang tenang, damai dan penuh kekerabatan. Dan hal inilah yang didambakan oleh masyarakat pada waktu itu. 


\section{Penutup}

Paparan di atas menunjukkan bahwa 3 faktor keberhasilan da'wah Islam diatas saling terkait. Artinya, kita tidak akan bisa memahami keberhasilan da'wah Islam diatas bila hanya dipahami secara parsial. Untuk lebih jelasnya dapat dipahami dari diagram di bawah ini:

Stoddard memandang Islam secara obyektif dengan mengemukakan 3 faktor penentu keberhasilan da'wah nabi diatas. Hal ini menjadikan kita semakin termotivasi untuk lebih menggali ajaran Islam yang dikatakan oleh Rodwell sebagai suatu ajaran yang memiliki vast energy suatu energi yang sangat luas, sangat dalam dan sangat luar biasa sekali.

Sebagai kesimpulan akhir kita kutipkan pendapat Stoddard;

Ia lahir digurun tandus. Penduduknya sedikit pengembara pula. Dan sebelum Islam datang mereka tak punya kedudukan dan tempat dalam sejarah. Tetapi kemudian dengan cepat sekali Islam berkembang kesegala penjuru duia, tanpa bantuan kekuasaan dan kekuatan banyak umat. Dalam kesulitan mahadasyat, Islam mendapat kemenangan nyata dan menakjubkan.

\section{Daftar Pustaka}

AhmadSyalabi, Masyarakat Islam, pen. Muchtar yahya, Djajamurni, Jakarta, MCMLXI, h

Badri yatim, Sejarah peradaban Islam, Raja Grafindo Persada, Jakarta 1998, h 21)

Ira M. Lapidus, Sejarah Sosial Umat Islam Bagian Satu dan Dua, Raja Grafindo Persada, Jakarta, h.33

Ibn Khaldun, pilihan dari Muqaddimah Filsafat Islam tentang Sejarah Charles Issawi Mukti Ali Tintamas Jakarta, 1976)

Mudjahid Abdul Manaf, Sejarah Agama-Agama, PT Raja Grafindo Persada, Jakarta, 1994

Philip K.Hitti, The Arabs A Short History, Dunia Arab Sejarah Ringkas, Pen.Usuludin Hutagalung, Sumur Bandung, 1962 
Ruslan Abdul Gani, Sejarah Perkembangan Islam di Indonesia, Pustaka Antar Kota, jakarta, 1983,

Saifudin Zuhri, Sejarah Kebangkitan dan Perkembangan di Indonesia, PT Al Maarif, Bandung 1981, h.20.

Syed Ameer Ali, The Spirit of Islam,pen Djamadi, Api Islam, PT Pembangunan, Jakarta, 1956 h.71

L.Stoddard, Dunia Baru Islam, Panitia Penerbit, Jakarta, 1966 